\title{
Prophetic mission of faith communities during apartheid South Africa, 1948-1994: an agenda for a prophetic mission praxis in the democratic SA
}

\section{Tobias M Masuku'}

\section{Abstract}

Prophetic mission praxis is increasingly becoming difficult in the democratic South Africa. This article unearths and analyses the prophetic role played by faith communities in South Africa during the apartheid regime. It focuses on different approaches adopted by each of the major faith communities in response to apartheid. The author categorises the role of faith communities into three viz; those that supported apartheid, those that rejected it and those that adopted what he refers to as 'quiet diplomacy' with regards to apartheid. Apart from Christian faith communities, the author also analyses the role played by other faith communities such as Islam and African Traditional Religions. Having this in mind, the author looks at the current situation with regards to the prophetic role of faith communities in the democratic South Africa and thereafter proposes a wayforward for a relevant prophetic mission praxis.

Keywords: Apartheid, faith communities, churches, Dutch Reformed Church, Nationalist Party, Daughter Churches, mission/missionary, African Initiated Churches, African Traditional Religions and Islam.

\section{Background}

Since 1948, the synods, conferences, and assemblies of the churches have protested against every piece of legislation they have considered unjust...The churches have spoken against race classification; the forced removal of population groups due to the Group Areas Act; the Immorality Act and Mixed Marriages Act, designed to preserve racial purity; the various education acts which have created separate kinds of education along ethnic lines; job reservations... (De Gruchy 1986:88).

Apartheid triggered different reactions in various sections of the South African (SA) society, including faith communities. De Gruchy (1986:58) referring to Christian communities writes that "some regard racial separation as scriptural, some as blatantly unscriptural, and others as pragmatically necessary but not ideal."

1 Dr Tobias Masuku is the Chief of Staff in the Chaplain General Division of the South African Department of Defence. He is also part-time Minister of Religion in the Uniting Reformed Church in Southern Africa, Delmas, Mpumalanga Province, South Africa. He can be contacted at masukumt@penta-net.co.za 
Reaction did not only come from the victims of apartheid but also from some members of the communities that benefited from the system. Notable examples are the late Drr Nico Smith and Beyers Naudé. Another figure in the same category is Prof Willem Saayman, an Afrikaner whose Afrikaans accent, according to Kgatla (in Karecki 2002:46) "testifies to this fact because his ' $r$ ' sounds are prominently pronounced" and who, according to Botha (in Saayman 2007:vii), was so trusted that he was elected ANC chairperson of the Pretoria branch at some stage. There are many examples of people who, while they were from the privileged communities that introduced and benefited from the system, ended up being champions in the fight against the injustice meted out by the apartheid system.

The reactions were also marked by divides among faith communities with regards to the approaches to fight this system. The divisions also reflected themselves in churches as they did not see things the same way. The churches were divided among those who embraced apartheid, those who rejected it and those who assumed a neutral position or 'quiet diplomacy'. This article attempts to outline and analyse the dynamics of these divides with regards to faith communities' approach to apartheid and how this could be a lesson in post-apartheid SA and beyond.

\section{Apartheid is embraced by churches}

Indeed the analysis of the NGK...shows that all its conferences from 1950 to the present (i.e. 1989) have more than proven that apartheid was conceived in the womb of the NGK in 1857. Thus, the election of the NP to political power in 1948 meant that the NGK would monitor the implementation of a policy that it had long advocated and practiced within its own structure. Consequently, apartheid was not only defended by NP ideologues such as Malan, Strijdom, Verwoerd, Vorster, Botha and others, but also by prominent NGK leaders and theologians (Ngcokovane 1989:180).

Apartheid ignited various responses from churches and some of them adopted and supported it. The Dutch Reformed Church (DRC) stands prominent in this regard. Although other Afrikaans speaking churches did not adopt an official position in support of apartheid as did the DRC, individually, their members supported the system. This could be judged by the continuous large voter support for the Nationalist Party by predominantly Afrikaner electorates, the majority of whom were Christians. The majority of Afrikaners formed part of what Bredekamp and Ross (1995:1) call "the approximately three-quarters of the SA 
Christians" who form the dominant part of the entire South African population. This point becomes clear in the reasons offered by the Federal Mission Council (FMC) of this church as to why the DRC followed the policy of apartheid (Strassberger 2001:190):

It is the conviction of the majority of Afrikaans speaking South Africans and the majority of the members of the DRC that the only way of ensuring the continued survival of the nation is by preserving the principles of racial separation. Racial integration on an extended scale, on the other hand, must result in the lowering of standards, culturally, morally and spiritually.

The link between the DRC and apartheid is very close in such a way that Saayman (2007:70) finds it difficult to trace the origin of apartheid between the Nationalist Party and the DRC. He likened it to the proverbial case of a chicken and egg. This makes it difficult to reach a decisive conclusion with regards to the originator of apartheid. The fact that the term 'apartheid' was coined by a DRC minister and theologian Prof Jeff Cronje, further cemented the marriage between this church and the Nationalist government which implemented it in the political arena in South Africa (De Saintonge1989:39).

Members of the DRC, because of their large membership and access to political power, were influential in every sphere of life in South Africa. De Gruchy (1986:69) observed that the DRC members dominated every aspect of life such as in Parliament, provincial and local government councils. He further noted that members of this church also dominated the public servants community such as the police and the military.

It would be unfair to state that all members or ministers of the DRC supported apartheid. Already during the Federal Council in 1953 at the peak of apartheid, figures such Prof B.B. Keet (in De Gruchy 1986: 58), a teacher at the Dutch Reformed Seminary in Stellenbosch, demonstrated that they held opposing view to apartheid when he conducted the opening address of the council. He stated:

Personally, I believe that our brethren who want to maintain apartheid on biblical grounds are labouring under this misunderstanding. They confuse apartheid, which is an attitude of life, with a diversity which includes unity. Christian unity, I know, will include diversity but it must never be seen as separation; and apartheid is separation.

Other voices opposing apartheid within the DRC, in addition to Prof Keet and others, were those of thinkers like Prof Ben Marais (ibid: 59). The problem was that those opposing voices were in the minority within the 'sea' of apartheid supporters. 
During the period under review, the DRC also transformed from being a racist, apartheid supporting church into a church that opened her doors to people of other races. However, this is something that is still in the process of completion at the moment. Already during the DRC General Synod of October 1986, cracks were beginning to be felt in this church's support for apartheid with the adoption of an open membership position. The cracks resulted in a division within the church which brought to birth the Afrikaanse Protestanse Kerk led by what König (1987:1) referred to as Die Beswaardes². During the DRC General Synod of 1990, cracks became even wider as could be seen by the following declarations made (Kerk en Samelewing 1990:14-21; cf Nederduitse Gereformeerde Kerk 1990):

- The Holy Scriptures regard the human race as one. ${ }^{3}$

- $\quad$ Race and colour play no role in the Biblical judgement of humankind. ${ }^{4}$

- Racism is a serious sin which no person or church should defend or practice. ${ }^{5}$

- The Christian neighbourly love is the ethical norm for fellow human relations. ${ }^{6}$

- The exercise of righteousness and justice is an important Biblical instruction. ${ }^{7}$

To sum up the above rejections of apartheid, the very 1990 General Synod also made a unanimous declaration on the official position of the DRC on apartheid:

The Dutch Reformed Church states that the handling of apartheid as a political and social system of injustice for most people and empowers one group above others, cannot be acceptable on the basis of Christian ethics because it is in conflict with the principle of neighbourly love and endangers the humanity of all involved (my translation, NGK ACTA General Synod 1990, Par 306).

Since the above synods, additional developmental processes were made with regards to the demise of what König (1987:1) referred to as "the Supper Apartheid in the church" (my translation) ${ }^{8}$. The process also saw the DRC being re-admitted into the various religious bodies nationally

2 The disgruntled.

3 Die Heilige Skrif beskou die menslike geslag as ' $n$ eenheid.

4 Ras-en kleurverskille speel geen rol in die Bybel se beoordeling van mense nie

5 Rassisme is ' $n$ ernstige sonde wat geen mens of kerk mag verdedig of beoefen nie

6 Die Christelike naasteliefde is die etiese norm vir mede-menslike optrede

7 Die beoefening van geregtigheid en reg is ' $n$ belangrike Bybelse voorskrif

8 Die Super-Apartheid in die Kerk. 
(e.g. the South African Council of Churches) and internationally (e.g. World Alliance of Reformed Churches). The fact that Dr Beyers Naudé 9 saw it fit to accept the apology from and an invitation to return to the DRC, suggests that this church made positive strides in the process of transformation. Naudé (in Clements 2006:171) admitted that

...there has been in many respects a tremendous change. First of all, the Dutch Reformed Church apologized to me and to others who opposed apartheid for mistakes they made. And we gladly accepted that. Secondly, I have said to the leaders of the Dutch Reformed Church: 'All of us must move forward to this establishing of the Uniting Reformed Church in Southern Africa where all of us, regardless of our ethnic background, our language, our race, must be one in the Reformed family in order to build the Kingdom of God.' But we must not remain only in the Reformed family. We must become part of the wider Body of Christ in South Africa where all of us contribute and make available this tremendous witness to the world.

The level of this change could also be measured against the fact that in 2010, the Western Transvaal synod of the DRC already had two Black African male ministers ${ }^{10}$ who have been called from the ranks of her so called daughter churches.

It could therefore be concluded that positive changes within the DRC cannot be underestimated. Despite this hopeful progress, the DRC is still unable to structurally unite with other churches of the DRC family.

\section{Apartheid is rejected by churches}

While there were churches that supported apartheid, others adopted a prophetic position against this policy. The predominantly English speaking churches are a point in case in this approach. For instance, the General Assembly of the Presbyterian Church of South Africa in September 1948 "criticised proposed legislations aimed at depriving Africans of their limited Parliamentary representation as a retrograde step contrary to the claims of the Christian responsibility" (De Gruchy

9 Dr Beyers Naude was a Minister in the DRC from 1940 until 1963. In 1963 he was forced to leave this church because of his disapproval of its support for apartheid. He was invited back to the DRC in 1994 and this church has since apologised to him. Since 1963 Dr Beyers Naude ministered to the victims of apartheid oppression and he was given a state funeral when he passed on in 2004 (Masuku 2010; cf Heaney 2004).

${ }^{10}$ Rev V.A. Magagula is attached to the congregation of Potchefstroom as a chaplain for non-Afrikaans speaking students (Jaarboek van die NG Kerke 2010:217) and Rev J. B. Moncho who is attached to the congregation of Mafikeng with special focus to the Chaplaincy of the South African National Defence Force as a Chaplain (Jaarboek van die NG Kerke 2010:299). 
1986:54). On the same position, the General Assembly's prayer was "that white South Africans may be saved from the contempt in the eyes of the world which such actions is bound to produce" (ibid).

During the same period as above (September 1948), the Methodist Church of Southern Africa also had a conference which released a statement that declared its position regarding the question of racism in South Africa,

...no person of any race should be deprived of constitutional rights or privileges merely on the grounds of race and morally binding contracts protecting such rights or privileges should be regarded on a high level of a pledged word (De Gruchy 1986:54).

The Methodist Church during this conference also advocated for the development of political and social rights especially for underprivileged groups. They contended that the rights of the underprivileged should not be reduced but rather expanded to the level of greater usefulness (ibid). Another church that added her voice against apartheid was the Congregational Assembly which wrote, "It is our sincere conviction that the Government's policy of apartheid has no sanction in the New Testament Scriptures...." (De Gruchy 1986:54).

The most formidable response against apartheid came from the Anglican Church of South Africa. The Episcopal Synod of the Church of the Province of South Africa issued a statement as early as 1948 in which they indicated that they identified themselves with the Lambeth Conference which declared that "discrimination between men on the grounds of race alone is inconsistent with the principles of the Christian religion" (De Gruchy 1986:55). The bishops also emphasized that human rights is rooted in Christian doctrine and apartheid should therefore be condemned at all costs.

This church action against apartheid could also be seen in the activities of the Anglican missionary, Father Trevor Huddleston who worked in Sophiatown in Johannesburg. Father Huddleston published a book in 1956 in which he told the story about the painful experience of his Black parishioners as meted out by apartheid. Many Anglican missionaries were deported by the government because of their strong opposition to apartheid, (De Gruchy 1986:60). The critical role played by Father Huddleston against racial discrimination in South Africa could be seen in the way Smith (in De Saintonge 1989:41) refers to him as, "that turbulent priest from the Community of the Resurrection, who has been a thorn in the flesh of the present regime for the last forty years or more." 


\section{Churches adopt a neutral stance (quiet diplomacy) on Apartheid}

Apart from the position taken by other religious communities as discussed above, there were other churches that adopted a neutral position on the apartheid question in South Africa. Neutrality qualified those churches that were characterized by a soft approach towards apartheid, adopting an ignorant position and accepted the political status-quo without questioning it.

Churches that belonged to this category were those from Pentecostal or Evangelical movements. Barret (in Knitter 1985:77) lists three types of Evangelicals:

- Fundamentalists, who still carry on the founding spirit of the Fundamentals and insist on the seven fundamental doctrines of authentic Christianity; inerrant verbal inspiration of the Bible, virgin birth, miracles of Christ, physical resurrection, total depravity of the human being, subsitutionary atonement and ,premillennial second coming.

- Conservative Evangelicals who want to carry on the intent of Fundamentalism but in a more open, critical style; most of them belong to the World Council of Churches.

- The Ecumenical or New Evangelicals.

The first two categories above represent the overriding characteristics of the Evangelicals. These characteristics could be seen from the criticism levelled against them by the New Evangelicals as summarized by Knitter (1985:77) that: "they (New Evangelicals) claim that Evangelicals in the past have been socially and politically naïve and have aligned themselves with the oppressive status quo."

This is still true today as could be seen from the critics levelled by the New Evangelicals to mainline churches. The Evangelicals believed that mainline Christianity eroded the heart of the Christian faith (ibid: 76) and stated that the:

New belief in evolution that questioned the veracity of the biblical accounts of creation; the recently born study of comparative religion and psychology that seems to place Christianity on par with other religions and the emergence of the "Social Gospel" within the Protestant churches that seemed to imply that God's kingdom could be brought about by social action rather than by spiritual transformation.

The Apostolic Faith Mission (AFM) of South Africa stands as an example of the Evangelical or Pentecostal Movement. Members of churches with Pentecostal characteristics regard themselves as passers-by in this world. 
They do not get involved in 'things of this world', commonly referred to as 'worldly things'. Their concern is mission, to get as many converts (with personal commitment to Jesus Christ) as possible before the return of Christ. In contrast to the DRC that adopted the government racial policy, the AFM did not officially adopt it nor questioned it, but "accepted the general racial pattern customary in South Africa" (Strassberger 2001:85). Different races were served in different congregations based on racial lines.

Another church that initially adopted a 'quite diplomacy' approach to apartheid was the Roman Catholic Church. De Gruchy (1986:97) puts it thus:

Neither the Roman Catholic Church nor...have been in the forefront of the struggle against racism in South Africa until fairly recently. At least it may be more accurate to say that they have not been as visible in this regard as the English-speaking churches.

The reason for this was the dominant Reformed Protestants in South Africa as represented by the DRC which had anti-Roman Catholic elements. The oppression of the Roman Catholic Church by the DRC could be seen in a Church Leaders' Conference held by the DRC in 1953 to which 'nonRoman Catholic' bodies were invited (Ngcokovane 1989:46). As a result of this anti-Catholic approach by the government, the Catholics suffered a strict control from a predominantly Protestant South African government (De Gruchy 1986:97). During the Cottesloe consultation, the Roman Catholic Church was not a member of the World Council of Churches (WCC) (Randall 1982:18). This was an indication that they adopted a 'quiet diplomacy' approach on apartheid.

The Roman Catholic Church issued two statements on race relations in South African in 1952 and 1957 respectively. In both statements, one sees a soft approach if not a contradiction on the condemnation of apartheid. While they seemed to condemn apartheid in principle, in the same breath they strongly recommended that apartheid should not be abolished once but through a process, evolution or gradual change. An extract from the 1957 statement reads thus:

The condemnation of the principle of apartheid as something intrinsically evil does not imply that perfect equality can be established in South Africa by a stroke of the pen. There is nothing more obvious than the existence of profound differences between sections of our population which make immediate total integration impossible. People cannot share fully in the same political and economic institutions until culturally they have a great deal in common. All social change must be gradual if it is not to be gradual....It would be unreasonable, therefore, to condemn indiscriminately all South Africa's differential legislations (Hofmeyr, Millard \& Froneman 1991::211). 
The Lutheran Church on the other side may be grouped to this category because during the 1970s, she was predominantly involved in internal struggles to unite the Black and White sections of the church. The Black synods that went their way in the 1970s tried to speak against racism but their energy was devoted to the struggle for unity which was complicated by what De Gruchy (1986:100) calls, "the conservative position adopted by most German-speaking Lutheran congregations."

Another silence on the condemnation of apartheid could be noted in the so-called daughter churches of the DRC ${ }^{11}$. The DRC dominated these churches in different spheres including finance. De Gruchy (1986:69) referring to this point adds that, "it has also considerable influence over the nearly one million members of its black 'daughter churches'." Ngcokovane (1989:46; cf Adonis 2005:120-121) indicates that the 'daughter' churches depended on 'mother' church for money and personnel. Already, in 1982 the DRC spent R12 million annually on the 'daughter' churches as a means of assistance (Cronje 1982:7). The DRC was usually referred to as 'mother' church or "Big Mama" (Buti 1982:63) in her relation to these churches. For this reason they were unable to speak out against the system adopted by their 'mother'. Under these circumstances, what Cronje (1982:5) referred to as a regular statement by leaders of the 'daughter' churches becomes questionable. The statement reads: "Autonomous in all respects we are; as to our origin, we have been born out of the DRC mission."

Taking one of the 'daughter' churches, the Dutch Reformed Church in Africa (DRCA) as an example, although it was established as autonomous, after many years of existence, Buti (1982:63) wrote concerning the continued domination of DRCA by ministers who were missionaries of the DRC:

The large number of whites serving as missionaries in this church naturally leads to a strongly domination role of such persons in controlling positions and decisions of the younger churches in the moderations, synods, crucial synodical commissions, theological lectures in theological seminaries of the DRCA and theological faculties of the state controlled Black universities.

This situation limited any opportunity for these churches to make their voices heard against their 'masters' who were controlling important areas of their lives. It was easy for DRC ministers to become members and in

11 These are churches that came into existence as a result of the mission work of the DRC. These 'daughter' churches were racially divided between the black Africans (Dutch Reformed Church in Africa), so-called Coloureds (Dutch Reformed Mission Church) and Indians (Reformed Church in Africa). 
particular ministers in the DRCA but the other way round was not allowed (Masuku 1998:76). Ministers of the DRCA were always looked upon with suspicion by fellow Black ministers from other churches because of their association with the church that was seen to be aligned with the DRC (ibid: 76). Although there were small voices such as the 'Black Ministers' Caucus' (Buti 1982: 87; cf Masuku 1998:76) in the DRCA, they did not represent the official stand-point of this church on race relations. They were a small minority and like the Lutherans, they were mainly focused on an internal struggle to bring unity within the racially divided DRC family.

The African Initiated Churches (AICs) also belong to this category. For those who may not be familiar with this type of churches called the African 'Initiated' Churches (AICs), a brief explanation is necessary. The most acceptable definition of these churches is by Hendriks (in Hofmeyr et al 1991:26) who wrote:

An African Independent or Indigenous Church is a purely blackcontrolled denomination with no links in membership or administrative control to any non-African church. In contrast to the black congregations that have been given self-supporting status by their missionary parents, the AICs have completely broken the umbilical cord with the Western missionary enterprise.

An additional definition is given by Masuku (1996:442-443) who shed some light on the confusion caused by the 'I' used for example as in 'Independent'. He warns that some of the AICs prefer each of these terms; 'Independent', 'Initiated' or 'Instituted.' He further indicated how they have been divided into three main groups namely; the Ethiopians, Zionists and Messianic. Masuku contends that the first group places more emphasis on independence but with the retention of pre-existing church patterns. The second group places more emphasis on the activities of the Holy Spirit in relation to African cultural practices. The last group represents those who built themselves around one leader. That leader claims special powers and 'eclipse' or replace Christ in their minds.

During the period under review, these churches' voice against apartheid was not heard. The fact that they failed to attract Black intellectuals within their ranks provides an answer on this matter. Masuku (ibid: 445) indicates that "the 'educated' looked down upon them as 'uneducated' and the 'sophisticated viewed them as 'primitive'." Masuku (1998:403) further indicates that "the general perception about these Christians (AICs) in South Africa is that they represent the constituency of the uneducated." They are referred to as 'red people' to indicate that they are fresh from tribal areas with almost no schooling (ibid). 
Although these churches did not openly attack apartheid, they assisted the victims of apartheid during migration to urban areas when they did not have food, accommodation and other needs. Hendriks (in Hofmeyr et al 1991:26) captured the situation when he writes that

...the process of urbanization was highly disruptive, because of the political and economic system forced on them. However, the African ethos of the extended family, of the tribal unity and care, was reincarnated to a certain extent in the African Independent Churches.

\section{Ecumenical Bodies}

Apart from individual responses from churches, there were also responses from the ecumenical front. For instance, the first ecumenical conference soon after the official introduction of apartheid was the Rosettenville Consultation that met in 1948. Rosettenville represented an official attack by the English speaking churches on the apartheid policy. (De Gruchy 1986: 56).

The second ecumenical body of note that convened during this period (1940s-1960) was the Cottesloe consultation. This body met in Cottesloe, Johannesburg from 7 to 14 December 1960 (Ngcokovane 1989:157). It was a meeting of the World Council of Churches (WCC) and her South African member churches to address, "the worsening racial situation in the country" (Randall 1982:18). The DRC delegates participated actively during the consultation and even accepted and signed the consultation statement against apartheid. This behaviour angered Prime Minister Verwoerd and the conservatives in the DRC. As a result of pressure from the Prime Minister and the DRC, the DRC delegation, except Beyers Naudé, recanted their stance and signatures against apartheid (Ryan 2005:64ff).

The third ecumenical move to address apartheid was through the formation of the Christian Institute (CI) of Southern Africa (Randall 1982:28). This body was formed by members from various races and denominations who met in the Central Methodist Hall in Johannesburg. The meeting took place on 13 August 1963 with an aim to; "meet together to try to work out the implications of the Kingdom of God for the people of the country" (Randall 1982:28; cf 2.4.2; see Heaney 2004:82). This purpose is further outlined by Kistner (1995:41) thus: "To draw attention to the injustice and disruption caused by the apartheid system in South African society and in the churches. It was founded to strengthen the resistance of Christians against that system." 


\section{Main minority religions}

There are many minority religions in South Africa but Islam, African Traditional Religions (ATR) and Hinduism stand supreme in terms of their numbers compared to other minorities. Kruger (1996:30) is correct in including some of these religions when he refers to "Africa's triple heritage." This heritage comprised Christianity, African Religion (meaning ATR) and Islam but he unfortunately excluded Hinduism. In my analysis of responses by minority faith communities against apartheid, attention will be on Islam, ATR and Hinduism due to their bigger number of adherents in South Africa, compared to other minority religions.

Muslims played an active role against apartheid through their organized religious structures. For instance, the Muslim Judicial Council (founded in 1945), was not only meant to promote Muslim unity, but also to "form a united front against oppressive laws of the day" (Kruger 1996:228). The Muslim Youth Movement of South Africa also made a mark against apartheid. Although this body initially encouraged self-and-group study of the Quran, "eventually, this group also became active in the political arena in the struggle against apartheid" (ibid).

As far as African Traditional Religion was concerned, during this period (1940s-1960), it was difficult to see any contributions they were making in the fight against social injustice. It was not easy for adherents of this religion to come out proudly like members of other faiths because of the stigma that was attached to them and their religion by missionary Christianity and the 'Christian' aligned apartheid state. The foundation of the stigma was laid during the early encounters between Western missionaries and indigenous communities in Africa. For instance, the latter's religion was referred to as "heathen cultures," "religion of the lower races" or "uncivilized" people and statements such as "the heathen in his blindness bows down to wood and stone" were common on the lips of missionaries (Setiloane 1976:104). They were deemed "archaic, barbaric and backwards" (Masuku 1998:21).

Another point of note is from Kruger (1996:34) who contended that African Religion forms an integral part of social life. The fact that religion and other social activities merge, makes the visibility of this religion low. This low visibility is due to the fact that most of the rites are performed in private. He continues to point out that even where the religious element is present in public, it is difficult for outsiders to identify it as such.

Adherents of ATRs have an open mind to other religions due to the absence of an intellectual statement of religious belief in dogmas (ibid: 36). This leaves adherents open to syncretism. It leaves the possibility 
that they, like in the case of the Hindus, might not have fought apartheid through their religious structures, but through organized social actions.

As far as Hindu faith is concerned, her adherents did not confront apartheid in an organized way within their religious structures during the period under review. The objectives of two Hindu movements in South Africa that were established during the period under review do not depict any focus on apartheid. For instance, the Ramakrishna Centre in South Africa whose main ashram (complex) was opened in Durban in 1959, is a point at stake. According to Kruger (1996:92), "the movement emphasizes and promotes the recognition of the divinity within every human being as a basis for both personal spirituality and social responsibility." The other movement called the Divine Life Society, though was founded in India, opened its South African centre in Durban in 1949 and recognized that all life, including every human being, is one with the divine (ibid:93).

It is a pity that, though these movements were established in South Africa during the apartheid rule, they did not have a direct prophetic message to government. Despite this, one cannot rule out the fact that some of the adherents of this religion participated in organized political structures of this country outside organized Hindu religious lines. Mahatma Gandhi (died in 1948), who is one of the builders of the Hindu faith, left an important legacy for prophetic ministry and social justice through peaceful means. He believed that his actions that include political, personal, family and social were part of religious duty. For instance, he said: "For me, the road to salvation lies through incessant toil in the service of my country and there through humanity" (Ibid).

\section{Diminishing prophetic voice of the church in Post-Apartheid SA}

The period under review represented a strong prophetic voice from churches and other faith groups. Although the prophetic ministry differed from one faith community to another, the general picture was that of also addressing injustices in state and society. In this article, I categorised faith communities that responded to apartheid into five namely; those that embraced apartheid, e.g. the DRC, those that rejected apartheid e.g. the Anglicans and the Methodists, those that adopted a neutral stance on apartheid e.g. the Evangelical Lutheran Church and the 'daughter' churches of the DRC, ecumenical bodies e.g. Cottesloe Consultation, main minority religions e.g. African Traditional Religions and Islam.

In comparing the degree of the church's prophetic voice during the apartheid and post-apartheid periods, the difference became apparent. 
While during apartheid the church was vocal against apartheid, she is silent today. For instance, while during apartheid mass protests were led by religious leaders, today their absence is apparent. While during the period under review the South African Council of Churches (SACC) and other Faith Based Organisations (FBOs) used to give a clear direction of events in the country, today one wonders if it still exists because of its stark silence.

Another point that silenced the prophetic voice of the church is the close relationship that exists between individual religious leaders and the post-1994 democratic government. Religious leaders who used to exercise their prophetic ministry during the apartheid government are today in the employ of the democratic government, occupying senior positions. This trend silenced them and they became recipients of petitions from victims of oppression during protest marches. They stand against the victims of oppression, taking the side of the state.

The church is expected to be prophetic at all times. Unfortunately, in the post - apartheid era, the church's prophetic voice has been silent. For instance, during the 2008 xenophobic violence in South Africa, the voice of the church was not heard in the way it used to speak during such incidents during apartheid. During post-apartheid SA, apart from the above example of xenophobia, many incidents have continued to happen, which have challenged the prophetic role of the church. Examples of these are the general decline in morals, manifesting itself in high levels of rape, torturous criminal activities and corruption predominantly in government. The church should therefore be in a position to minister to all sectors of society including the state.

\section{Conclusion}

This article revealed an interesting scenario with regards to the reaction of faith communities to apartheid. The divide among religious communities with regards to their approach was absolute. It is possible to categorise faith communities into three distinct classes, based on how they responded to apartheid in their ministry. The line ran between, firstly, those that supported apartheid, secondly, those that rejected it and thirdly, those that elected to adopt a 'no comment' approach i.e. quiet diplomacy approach. Although two of these categories (the second and third categories) did not exercise a prophetic ministry to apartheid government, the only category that practised prophetic ministry had a loud voice which made a great impact.

The post-apartheid scenario presented itself with a different environment which considerably affected faith communities which were at the forefront of the prophetic ministry during apartheid. Some of the faith 
leaders who were vocal against apartheid are in the employ of the current post-apartheid government, toothless in terms of the application of prophetic ministry. For instance, the existence of the SACC was felt at every corner of the apartheid South Africa. Strangely, today one can be forgiven to think that SACC exists no more.

How can faith communities, especially the leadership, be relevant to the current situation as well as when we face the future? The nature of the relationship that currently exists between the leadership of faith communities and the current democratic government should be revisited and redefined. The relationship should be shaped in such a way that it frees the leadership of faith communities from the employ by the government in order to apply their prophetic mission praxis without bias.

\section{Bibliography}

Adonis, J C 2005. Dr Beyers Naudé and Church Unification in the Family of Dutch Reformed Church, in The Legacy of Beyers Naudé Beyers. Naudé Centre Series on Public Theology Volume 1. Stellenbosch: Sun Press, 117-126.

Bredekamp, H \& Ross, R 1995. Missions and Christianity in South African History. Johannesburg: Wits University Press.

Buti, S P E 1982. Black Experience and the Struggle for Liberation in the Relationship between the White Dutch Reformed Church and the Black Dutch Reformed Church. M.Th Dissertation. Princeton Theological Seminary.

Clements, K W 2006. An interview with Beyers Naudé, in Hansen, L \& Vosloo, R (eds), Oom Bey for the Future: Engaging the witness of Beyers Naudé. Beyers Naudé Centre Series on Public Theology Volume 2. Stellenbosch: Sun Press, 167-172.

De Gruchy, J 1986. The Church Struggle in South Africa. $2^{\text {nd }}$ ed. Claremont: David Phillip.

De Saintonge, R 1989. Outside the Gate: The Story of Nico Smith. London: Holder and Stoughton.

Cronje, J M 1982. Born to Witness. A Concise History of the Churches born out of the mission work of the Dutch reformed Church. Pretoria: NG Kerkboekhandel.

Heaney, M J 2004. Beyers Naudé, Ekumeniese Baanbreker in Suid-Afrika: 1960-1994. PhD thesis, University of Pretoria. 
Hofmeyr, J W, Millard, J A \& Froneman, C J J (eds) 1991. History of the Church in South Africa. A document and source book. Pretoria: UNISA.

Jaarboek van die NG Kerke 2010. Wellington: Tydskriftemaatskappy.

Karecki, M (ed) 2002. The Making of An African Person: Essays in Honour of Willem A. Saayman. 1st ed. Pretoria: Daan Roux.

Kerk en samelewing 1990. 'n Getuienis van die Nederduitse Gereformeerde Kerk: Soos aanvaar deur die Algemene Sinode van die Ned Geref Kerk, Oktober 1990.

Kistner, W 1995. Beyers Naudé's Witness: A Pauline Interpretation, in Villa-Vicencio, C \& Niehaus, C (eds), Many Cultures, One nation. Johannesburg: Human and Rousseau.

Kgatla, S T 2002. Willem Saayman, A True African Afrikaner Missiologist, in Karecki, M (ed), The Making of an African Person: Essays in honour of Willem A Saayman. Menlo Park: SAMS, 46-55.

Knitter, P E 1985. No Other Name. A Critical Survey of Christian Attitudes Toward the World Religions. London: SCM Press.

König, A 1987. Super-Apartheid in die kerk. Die oortuigings van die beswaardes volgens 'Geloof en Protes'. Pretoria: NG Kerkboekhandel, Transvaal.

Kruger, J S, Lubbe, G J A \& Steyn, H C 1996. The Human Search for Meaning. A Multi-religious Introduction of the Religions of Humankind. Goodwood: National Book Printers.

Masuku, M T 1996. African Initiated Churches: Christian Partners or Antagonists. Missonalia 24 (3), 441-455.

Masuku, M T 1998. Listening to the forgotten voice: Some views of AIC leaders on theological education. Missionalia 26 (3), 392-411.

Masuku, M.T 2010. The Ministry of Dr Beyers Naude to the victims of oppression: Towards Developing a Comprehensive (Communication) Strategy towards the victims of oppression. PhD Thesis, University of Pretoria.

Nederduitse Gereformeerde Kerk. Algemene sinodesitting, Oktober 1990. ACTA van die Agemene Sinodesitting 1990. Argief van die Nerderduitse Gereformeerde Kerk, Stellenbosch.

Ngcokovane, C 1989. The Demons of Apartheid. A moral and ethical Analysis of the N.G.K, N.P. and Broederbond's justification of Apartheid. Braamfontein: Skotaville. 
Randall, P (ed) 1982. Not Without Honour: Tribute to Beyers Naudé. Johannesburg: Raval Press.

Ryan, C 2005. Beyers Naudé. Pilgrimage of faith. $2^{\text {nd }}$ ed. Claremont: David Philip Publishers.

Saayman, W 2007. Being Missionary, Being Human. An Overview of Dutch Reformed Mission. Piertermaritzburg: Cluster Publications.

Setiloane, G M 1976. The Image of God Among the Sotho-Tswana. Rotterdam: Balkema.

Strassberger, E 2001. Ecumenism in South Africa 1936-1960 (with special reference to the church). Doctoral Thesis. University of Stellenbosch. Johannesburg: Zenith. 